\title{
The Rhine delta - a record of sediment trapping over time scales from millennia to decades
}

\author{
Hans Middelkoop • Gilles Erkens • Marcel van der Perk
}

Received: 9 January 2010 /Accepted: 1 April 2010/Published online: 21 April 2010

(C) The Author(s) 2010. This article is published with open access at Springerlink.com

\begin{abstract}
Purpose At the land-ocean interface, large river deltas are major sinks of sediments and associated matter. Over the past decennia, many studies have been conducted on the palaeogeographic development of the Rhine delta and overbank deposition on the Rhine floodplains. This paper aims to synthesise these research results with special focus on the amounts and changes of overbank fines trapped in the Rhine delta and their controls at different time scales in the past, present and future.

Materials and methods Sediment trapping in the Rhine delta throughout the Holocene was quantified using a detailed database of the Holocene delta architecture. Additional historic data allowed the reconstruction of the development of the river's floodplain during the period of direct human modification of the river. Using heavy metals as tracers, overbank deposition rates over the past century were determined. Measurements of overbank deposition and channel bed sediment transport in recent years, together with modelling studies of sediment transport and deposition have provided detailed insight in the present-day sediment deposition on the floodplains, as well as their controls.

Results and discussion Estimated annual suspended sediment deposition rates were about $1.4 \times 10^{9} \mathrm{~kg}_{\text {year }}{ }^{-1}$ between 6,000 and 3,000 years BP and increased to about $2.1 \times 10^{9} \mathrm{~kg}_{\text {year }}{ }^{-1}$ between 3,000 and 1,000 years BP. After the rivers were
\end{abstract}

Responsible editor: Ellen Petticrew

H. Middelkoop $(\bowtie) \cdot$ G. Erkens $\cdot$ M. van der Perk

Department of Physical Geography, Utrecht University,

P.O. Box 80115, 3508 TC Utrecht, The Netherlands

e-mail: h.middelkoop@geo.uu.nl

G. Erkens

Deltares,

P.O. Box 85467, 3508 AL Utrecht, The Netherlands embanked by artificial levees between 1100 and 1300 AD, the amount of sediment trapped in the floodplains reduced to about $1.16 \times 10^{9} \mathrm{~kg}$ year ${ }^{-1}$. However, when accounting for reentrainment of previously deposited sediment, the actual sediment trapping of the embanked floodplains was about $1.86 \times 10^{9} \mathrm{~kg}$ year $^{-1}$. Downstream of the lower Waal branch an inland delta developed that trapped another $0.4 \times$ $10^{9} \mathrm{~kg} \mathrm{year}^{-1}$ of overbank fines. Since the width of channel was artificially reduced and the banks were fixed by a regular array of groynes around 1850, the average rates of deposition on the embanked floodplains have been $1.15 \times 10^{9} \mathrm{~kg}_{\text {year }}{ }^{-1}$. Scenario studies show that the future sediment trapping in the lower Rhine floodplains might double.

Conclusions The variations in amounts of sediment trapped in the Rhine delta during the past 6,000 years are largely attributed to changes in land use in the upstream basin. At present, the sediment trapping efficiency of the floodplains is low and heavily influenced by river regulation and engineering works. Upstream changes in climate and land use, and direct measures for flood reduction in the lower floodplains, may again change the amounts of sediments trapped by the lower floodplains in the forthcoming decades.

Keywords Floodplains · Holocene · Preservation · River deltas $\cdot$ Sedimentation · Trapping efficiency

\section{Introduction}

At the land-ocean interface, large river deltas are major sinks of sediments and associated matter, such as contaminants, carbon and nutrients. This filtering function has a profound impact on the material fluxes from the continent into the coastal zones and oceans (e.g., Bianchi and Allison 2009). As a result of the continuous deposition of sediments and 
associated constituents, river deltas can provide important records of changes in climate, land use and direct human modification of the river system. Human interference has not only affected the river deltas as places of intense land use and with dense population and industrial activities but also through changes to the land cover of the upland catchment and modifications to the upstream river channel (for example, by damming, dredging or channelisation). Both natural and human impacts have greatly affected fluxes and quality of water and sediment in many major river basins across the globe during the past centuries to millennia (Syvitsky 2003). Considering the potentially large impacts on the river system, their effects are often detectable in the depositional record of large river deltas. This, in turn, makes large river deltas important natural archives for reconstructing past environmental changes in the upstream river system.

A necessary prerequisite for reconstructing past changes in river systems from deltaic deposits is that sediments from past times representing different conditions of climate, land cover and human impact have been preserved and can be identified with sufficient spatial and temporal resolution. The Holocene Rhine-Meuse delta forms a unique palaeoenvironment to study sediment trapping on a millennia timescale. This delta contains a relatively complete geological record, as a result of rapid aggradation during the Holocene, governed by eustatic sea level rise and land subsidence (Törnqvist 1993; Berendsen and Stouthamer 2000; Gouw and Erkens 2007). During the past decades, the palaeogeographic development of the delta has been extensively studied and an extremely detailed database of the Holocene delta architecture has been established (Berendsen and Stouthamer 2000; Berendsen and Stouthamer 2001; Gouw 2008).

Sediment trapping in the Rhine delta continued until man started large-scale river management and engineering works to protect the cultivated and occupied land in the delta from flooding. The construction of dikes and embankments commenced around $1000 \mathrm{AD}$, which constrained the river and completely prevented flooding and sediment deposition in the floodplain area behind the dikes. In the mid-nineteenth century, the river channel was further constrained by reducing the channel width and protecting the banks from lateral erosion by a regular array of groynes. These activities have greatly impacted the deposition of sediments upon the floodplain. Presently, many floodplain rehabilitation plans are being implemented for ecological rehabilitation of the embanked floodplains and to increase the discharge capacity of the river. To assess future changes in sediment deposition rates, it is essential to have detailed insight in natural and historic variations in these rates.

In this paper, we aim to synthesise a series of research results that have been obtained in recent years on sediment deposition in the Rhine delta. We summarise and discuss the amounts of overbank fine sediments trapped over different time scales in the past. We consider the millenniacentury time scale for the period 6000-1000 BP, a century time scale for the period after embankment of the rivers in the late Middle Ages, a decennial time scale for the period after large-scale river normalisation works in the mid-nineteenth century, recent sedimentation rates and scenario estimates for sediment trapping for the next 50 years.

\section{Study area}

The Rhine delta in The Netherlands (Fig. 1) is one of the largest and most complete sediment sinks in the Rhine river basin (Hoffmann et al. 2007) and presently covers an area of about $3,100 \mathrm{~km}^{2}$. At present, the Rhine discharges about $2,200 \mathrm{~m}^{3} \mathrm{~s}^{-1}$ with an average annual suspended sediment load of $3.1 \times 10^{9} \mathrm{~kg} \mathrm{year}^{-1}$ (Middelkoop and Van Haselen 1999). The Waal branch is the main distributary, carrying two thirds of the Rhine discharge and suspended sediment load.

Since the onset of deltaic deposition about 9,000 years ago, the Rhine delta has been a near-complete sediment trap for Rhine sediments (Beets and Van der Spek 2000; Erkens 2009). Sediment was mainly trapped in the back-barrier area in the central part of The Netherlands, where sea-level rise resulted in up to $20 \mathrm{~m}$ of accumulated Holocene deposits (Erkens et al. 2006; Hijma et al. 2009). Holocene aggradation in the Rhine delta started around 9,000 cal year BP in the downstream area and gradually shifted upstream to start around 5,000 BP in the upstream part of the delta (Gouw and Erkens 2007). Proximal to the channel, overbank deposits are mainly sandy and silty clays, in more distal flood basins they consist of silty clay and clay. The total thickness of the fluvial overbank deposits increases from about $1 \mathrm{~m}$ near the delta apex to over $10 \mathrm{~m}$ in the near-coast area. The upstream part of the delta is characterised by wide meandering channel belts and the flood basins almost entirely consist of clastic deposits. Downstream (towards the West) channel belts become narrower and are larger in number. In the flood basins, organic beds of increasing thickness occur, intercalated by clastic overbank deposits from the fossil river channels (Berendsen and Stouthamer 2000; Cohen 2003; Gouw and Erkens 2007).

Between 1000 and $1350 \mathrm{AD}$, local dikes protecting flood basins from inundation were merged, resulting in the complete embankment of the Rhine distributaries (Middelkoop 1997; Hesselink 2002). Between the dike and the river channel, a few hundreds of metres wide active floodplain ("embanked floodplains") remained subjected to fluvial processes. Within the confines of the dikes, sand and clay were both deposited and eroded by the river. The distal floodplain had become disconnected from the river.

Due to two storm surges from the North Sea and two floods of the river Rhine between 1421 and $1424 \mathrm{AD}$, 


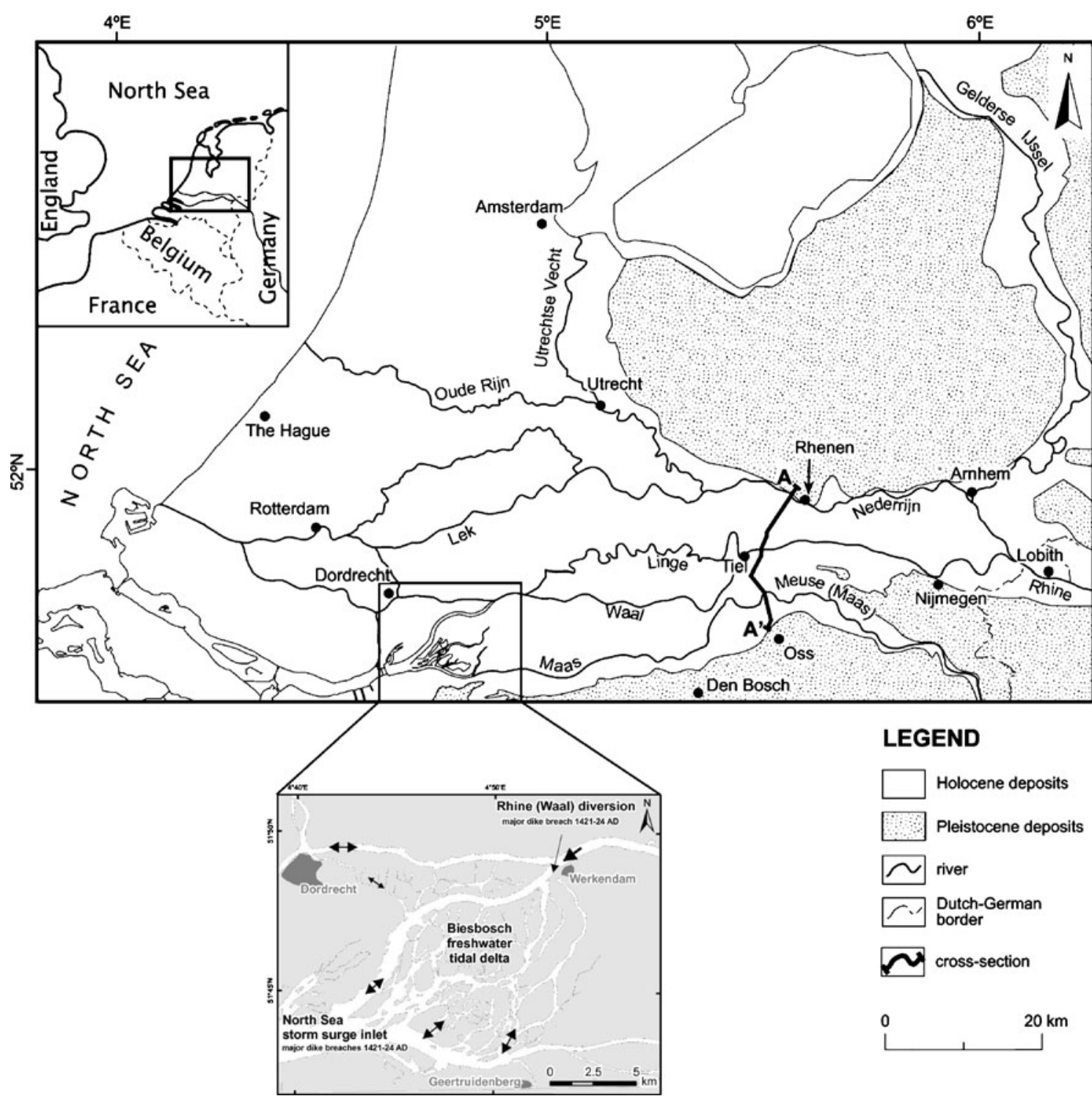

Fig. 1 Rhine delta in The Netherlands with main distributaries. The inset shows the Biesbosch inland delta (modified from Kleinhans et al. (2010))

commonly known as the St. Elisabeth flood, a previously reclaimed area in the southwestern part of the Rhine delta was inundated. In about two centuries following the catastrophic inundation, half the inundated area was filled up by a shallow deltaic splay which is $85 \mathrm{~km}^{2}$ in size and up 9 to $4 \mathrm{~m}$ thick, consisting of channel bed sands covered by a 1- to 2-m thick layer of silty clays (Kleinhans et al. 2010). This area became known as "the Biesbosch" and functioned as a major trap of suspended sediments between about 1600 and $1850 \mathrm{AD}$, until it was almost entirely protected from flooding by artificial levees.

By the seventeenth century, local minor levees ("summer dikes") were erected along the channel margin to prevent the embanked floodplain from being inundated by minor floods during the growing season. However, when these summer dikes are overtopped, the embanked floodplains function as a sediment trap. In the mid- and late-nineteenth century, the Rhine distributaries were 'normalised', which implied the straightening of meander bends, construction of groynes, reduction of the channel width and lateral fixation of the river channel (Middelkoop and Van Haselen 1999). At some places, the channel bed was armoured with concrete, while banks were protected by riprap. The river normalisation works stopped the lateral river channel migration, which resulted in the transport and deposition of sand to become almost exclusively limited to the channel bed, typically in the form of migrating ripples and dunes. Only at high discharge was sand washed onto the channel banks, forming small natural levees. More importantly, river normalisation enhanced the preservation potential of embanked-floodplain clays, because it put an end to erosion of floodplain deposits by migrating channels. 
At present, the total surface area of the embanked floodplains is $286 \mathrm{~km}^{2}$, which is $5.6 \%$ of the total floodplain area. A typical profile in the embanked floodplains consists of a clay layer of up to about $2 \mathrm{~m}$ in thickness, on top of sandy channel/point-bar deposits, with occasional residual channel fills of several metres (Middelkoop 1997; Hesselink et al. 2003). The principal land use in the embanked floodplains is pasture land; in some areas, reversion to natural wetland conditions has occurred (e.g. in residual channels or old clay pits). The main industrial activity is structural-ceramics manufacture, including clay extraction; several brick and roof-tile plants are present, built on flood-free mounds.

\section{Methods}

\subsection{Millennial scale (6000-1000 BP)}

To reconstruct the trapping of fine overbank deposits in the Rhine delta at the millennial time scale, the following steps were pursued (Erkens et al. 2006): (1) determination of the total amount of mid and late Holocene, Rhine-derived fluvial sediments in the Rhine-Meuse delta; (2) exclusion of channel-belt deposits (gravel to fine sand) and organics and (3) dating of sediment layers.

The total amount of Holocene fluvial sediment in the Rhine delta was determined using a database of 200,000 borehole descriptions (Berendsen and Stouthamer 2001). This database was queried for all borings that reached the HolocenePleistocene interface. Using the borings selected from the database, we created a digital elevation model (DEM) of the Late Pleistocene surface at a spatial resolution of $250 \times$ $250 \mathrm{~m}$. This DEM was subtracted from the DEM of the modern surface at the same spatial resolution. The surface DEM had been derived by resampling a 1-m DEM based on laser altimetry (data from Ministry of Transport, Public Works and Water Management). Multiplication of the sum of the resulting thickness of the Holocene deposits by the grid cell size yielded the total deltaic volume.

The northern and southern limits of the delta, where fluvial deposits thin out against higher topography (last glacial cover sands, draped over older landforms), were defined as the zone where the fluvial overbank deposits are less than $1 \mathrm{~m}$ thick. The south-eastern part of the delta contains considerable amounts of Meuse sediments, whilst sedimentation dynamics downstream the Rhine-Meuse confluence are dominated by the Rhine that discharges ten times more water than the Meuse. Therefore, we excluded all Meuse sediments deposited upstream of the most eastern confluence, which has shifted in time, from further analysis. We considered the Dutch-German border as the eastern limit, where the delta now grades into the lower valley. Towards the west, fluvial deposits grade into tidally influ- enced deposits (estuaries, inlets, lagoons). We included fluvial lagoonal deposits in the central Netherlands as these sediments are probably all Rhine sediments, but we excluded marine deposits. The western limit was defined where lagoonal peat forms the maximum proportion of the total Holocene thickness (see Erkens et al. (2006) for more details).

To determine the amount of overbank fines, we used a detailed cross-section across the Rhine delta oriented perpendicular to the general flow direction (see Fig. 1). This crosssection was compiled by Cohen (2003) from a total of 286 borings retrieved from the archives at Utrecht University (Cohen 2003; Berendsen 2005). The average borehole spacing in the cross-section is less than $100 \mathrm{~m}$ to obtain an adequate overview of the lithostratigraphy (Weerts and Bierkens 1993). It was classified into channel belts represented by relatively large sand bodies and associated overbank deposits. The overbank deposits were further subdivided into natural levee deposits, crevasse-splay deposits and clayey floodplain deposits. Peat and organic mud, commonly found in the floodplain, were included in an "organics" unit.

To determine the changes in fine sediment deposition through time, isochrones for 1,000-year intervals were constructed for each cross-section based on datings of sediment. This procedure is illustrated in Fig. 2. Approximately $28{ }^{14} \mathrm{C}$ dates of floodplain deposits provide the framework for the isochrones. Further, dating evidence used to construct time lines is the established period of activity of the channel belts and the associated overbank deposits. The period of activity of the channel belts was based on Berendsen and Stouthamer (2001) and Cohen (2003): the beginning of activity of a channel belt was assumed to correlate with the base and the end of the activity with the top of the overbank deposits of the associated overbank deposits. In the floodplain, peat and darkcoloured palaeo-A-horizons (e.g. Berendsen and Stouthamer 2001), which represent periods of little or no sedimentation, were interpreted as associated time markers. Where the abovedescribed techniques were ineffective, timelines were reconstructed based on the output of a 3D groundwater level model (Cohen 2005). The proportion of silt and clay deposits per time slice was calculated from the cross-section, and subsequently, the proportion was multiplied by the total volume of the Holocene fluvial sediments to obtain the total volume of overbank fines in the Rhine delta. For this study, the results of individual 1,000-year time slices were combined to derive two time slices: 6,000-3,000 cal year BP and 3,000-1,000 cal year BP. The volumes were converted to mass by assuming a density of $1,300 \mathrm{~kg} \mathrm{~m}^{-3}$ for all overbank sediments.

These results prove to be robust as they match well with the results of Erkens (2009), who calculated deposited volumes for the same time period in more detail and with a different method (e.g. using more cross-sections). Obviously, the results in this paper represent the preserved volumes of clay deposits. However, Erkens (2009) determined that preservation 


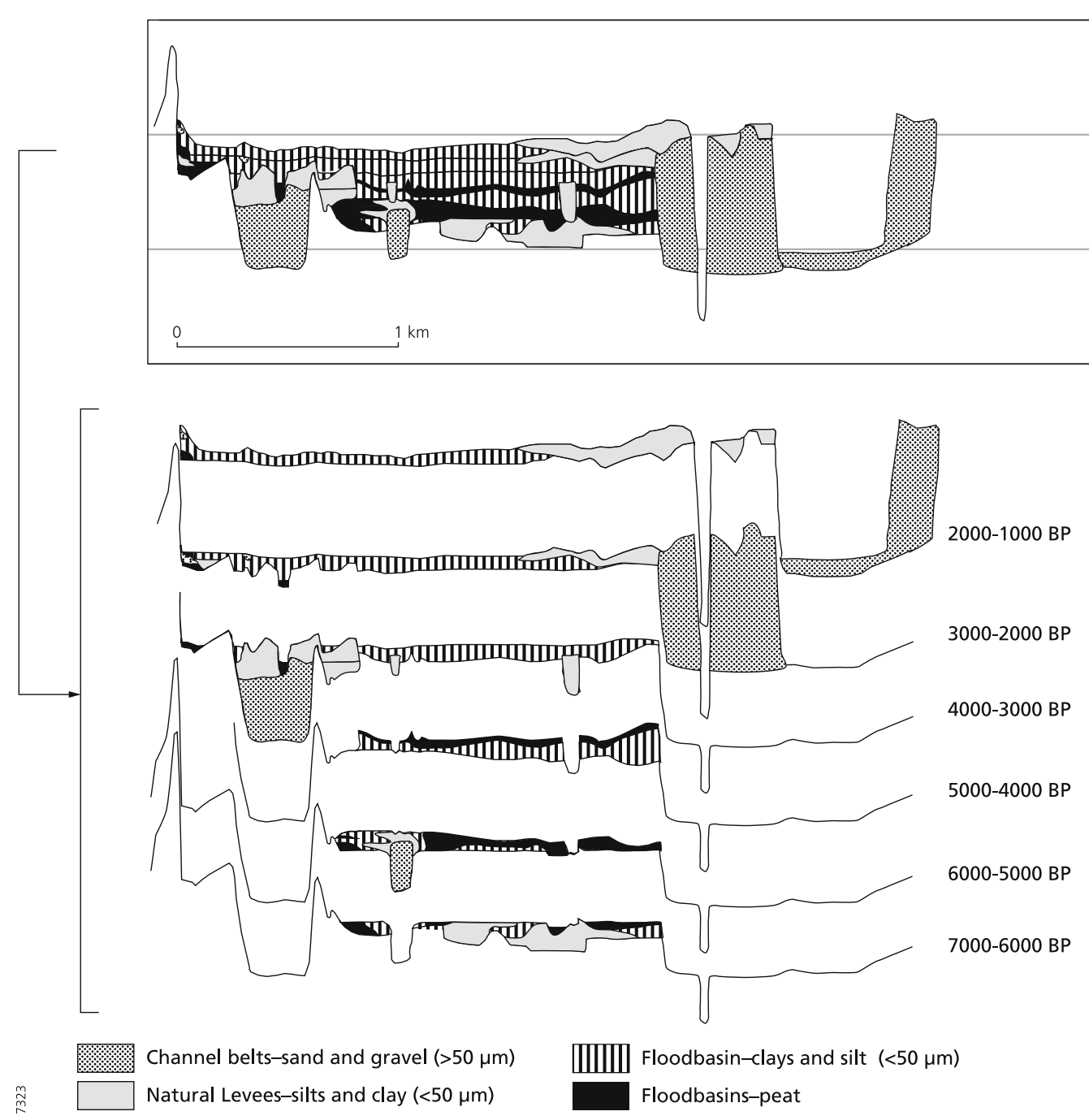

Fig. 2 Part of the central cross-section (A-A' in Fig. 1) (Cohen 2003; Erkens et al. 2006), subdivided in successive 1,000-year time slices based on isochrones

of the delta was high during the Holocene and that on average $82 \%$ of the suspended load deposits were preserved, a value which is expected to be even higher for the last 6,000 years.

\subsection{Deposition after embankment}

Channel dynamics reconstructed using previous studies of old river maps (Middelkoop 1997; Wolfert 2001; Hesselink 2002). By comparing time sequences of old river maps of different age mutually and with the present-day floodplain geomorphology, it was possible to reconstruct for many floodplain sections the changes in channel position, lateral channel migration and associated changes in floodplain area since about $1600 \mathrm{AD}$. The applied method is described in detail by Hesselink (2002).

The occurrence of superficial clay deposits in the embanked floodplains was assessed using a 3D clayresource model presented by (Van der Meulen et al. 2005,
Van der Meulen et al. 2007). This geo-cellular model was obtained by a 3D interpolation of lithological composition (i.e. proportions of clay, sand, gravel, etc.), using about 380,000 borehole descriptions. Model raster dimensions are $250 \times 250 \times 0.2 \mathrm{~m}$ down to $3 \mathrm{~m}$ below the surface and $250 \times$ $250 \times 1 \mathrm{~m}$ below that level. From these data, clay volumes within the embanked floodplains were identified by analyses of vertical model-cell stacks. These volumes were considered as the total volume of clay deposition since embankment that has been preserved until to date (Hesselink 2002). However, during the 1300-1850 AD time, slice major parts of the embanked floodplains were eroded by lateral channel migration. Thus, the amounts of sediments that have been preserved are considerably smaller than the amounts of overbank fines that were actually deposited. We, therefore, separately calculated this actual amount of deposition by multiplying the preserved amounts of overbank fines from this period by $(1+\mathrm{R})$, where $\mathrm{R}$ is the fraction of the area that 
was reworked by the river during the period. The surface area of reworked floodplains was estimated using old river maps that document lateral migration of the river channel over the past centuries, in combination of floodplain morphology that reflects a former position of the river channel (Middelkoop 1997; Hesselink 2002).

To estimate the amount of fine overbank deposits in the Biesbosch area, we used the data collected by Kleinhans et al. (2010). They used 360 borehole descriptions documenting the deltaic splay deposits from three sources: (1) data from the archives at Utrecht University, (2) data from the database of $\mathrm{TNO} / \mathrm{Geological}$ Survey of The Netherlands and (3) data of Zonneveld (1960).

\subsection{Deposition since 1850 normalisation}

The normalisation works around 1850 coincided with the onset of the Industrial Revolution, which led to a significant increase of the metal loads in the Rhine River (Middelkoop 2000). These increased loads are well reflected in floodplain deposits as increased metal concentrations. Therefore, we identified the overbank deposits formed after the 1850 normalisations on the basis of their increased heavy metal concentrations $(\mathrm{Pb}$, $\mathrm{Zn}, \mathrm{Cu}$ and $\mathrm{Cd}$ ). For this purpose, we used the data collected by Middelkoop (1997, 2000, 2002) and Hobo et al. (2010), which include heavy metal profiles taken along transects perpendicular to the main channel in various floodplain sections along each Rhine distributary. In total, these data comprised 13 profiles along the IJssel, eight along the Nederrijn-Lek, and 22 profiles along the Waal. First, we used the dating results that were obtained by Middelkoop (2002) and Hobo et al. (2010). Second, for each distributary, we determined the average proportion of the vertical profiles with elevated metal concentrations compared to the metal concentrations in the deepest part of the profiles. This provided an estimate of the average proportion of the overbank fines that were deposited after $1850 \mathrm{AD}$ along each distributary.

\subsection{Contemporary and future sedimentation rates}

Contemporary sedimentation rates were determined from measured overbank deposition during flood events using sediment traps (Middelkoop and Asselman 1998; Thonon 2006) and using model calculations (Van der Perk et al. 2008; Straatsma et al. 2009). We used a combination of a hydrodynamic model (WAQUA) that simulates the 2D waterflow patterns (Ministry of V\&W 2009) and a sedimentation model (SEDIFLUX) that simulates sediment transport and deposition (Middelkoop and Van der Perk 1998; Straatsma et al. 2009). We ran WAQUA for 13 steady-state Rhine discharges between 3,500 and $16,000 \mathrm{~m}^{3} \mathrm{~s}^{-1}$ at Lobith near the German-Dutch border. The average annual flow durations for the present situation were derived from the observed daily Rhine discharges at Lobith between 1901 and 2007. The associated suspended sediment concentrations in the lower Rhine were obtained using a sediment rating curve (Thonon 2006). Model-parameter values used in SEDIFLUX for sediment-settling velocity $\left(6.7 \times 10^{-5} \mathrm{~m} \mathrm{~s}^{-1}\right)$ and critical bed-shear stress for sedimentation $\left(2.0 \mathrm{~N} \mathrm{~m}^{-2}\right)$ were assigned based on previous modelling studies (Middelkoop and Van der Perk 1998; Asselman and Van Wijngaarden 2002; Thonon et al. 2007). The annual average sediment deposition rates were calculated using the discharge frequency distribution and the sediment rating curve.

To estimate the potential changes in future sediment deposition on the embanked floodplains, we considered climateinduced upstream changes in river discharge and suspended sediment yield in the river as well as various measures for flood reduction and restoring natural conditions in the embanked floodplain area, projected to the year 2050 (Straatsma et al. 2009). We used the climate projections provided by the Royal Dutch Meteorological Survey (KNMI) (Van den Hurk et al. 2006), from which we applied the KNMI-W scenario. This scenario assumes a $2^{\circ} \mathrm{C}$ increase in temperature, a change in precipitation of $+6 \%$ in winter and $-5 \%$ in summer and an $8 \%$ increase in summer evaporation from 1990 to 2050. The flow durations for the $2050 \mathrm{KNMI}-\mathrm{W}$ climate scenario were calculated following the methodology presented in Thonon (2006). Suspended sediment concentrations for the 2050 scenario calculations were obtained by adopting the sediment rating curve estimated by Thonon (2006): $C_{2050}=25.5+$ $1.96 \times 10^{-6} Q^{1.89}$, where $C_{2050}=$ the suspended sediment concentration estimated for the year $2050\left(\mathrm{mg} \mathrm{l}^{-1}\right)$ and $Q=$ discharge at Lobith $\left(\mathrm{m}^{3} \mathrm{~s}^{-1}\right)$.

The future landscape of the embanked floodplains may drastically change, depending on the measures that may be undertaken for flood reduction, nature development, recreation, infrastructure and other use of the floodplain area. Scenarios for the layout of the floodplains of the River Waal in the Netherlands for 2050 were obtained from Straatsma et al. (2009), who used a new value-based methodology for this purpose. Three fundamentally different sets of landscaping measures were defined that might be implemented by the year 2050:

- A relativistic scenario ("green"); measures comprise side channels with naturally vegetated banks, 32 floodplain lowering projects, three dike section relocations, minor embankment removal and natural management of floodplain ecotopes.

- A materialistic scenario ("orange") characterised by a productive-efficient layout. Measures comprise deep side channels, 51 floodplain lowering projects, minor embankment removal and emphasised agricultural production.

- A systemic scenario ("yellow") with a diverse pattern of city expansion, nature development, agricultural production and innovative groyne lowering. It comprised 
52 floodplain height change projects, minor embankment removal outside the production regions and seven dike repositioning projects.

For each scenario, the landscaping measures were translated into a future topography and hydraulic roughness distribution, implemented in the WAQUA-SEDIFLUX models, and run for the future discharge and suspended sediment loads in the Waal branch.

\section{Results and discussion}

The total mass of Holocene overbank fines currently present in the entire Rhine delta amounts to about $15.8 \times 10^{12} \mathrm{~kg}$, of which $93 \%$ was deposited before river embankment between 1100 and $1300 \mathrm{AD}$ and 7\% afterwards. Table 1 and Fig. 3 summarise the total volumes and masses of overbank fines deposited in the delta during the considered time slices in after 6000 BP.

\subsection{Middle Holocene (6000-3000 BP) deposition rates}

Between 6000 and 3000 BP about $4.1 \times 10^{12} \mathrm{~kg}$ overbank fines were deposited, which corresponds to an average sedimentation rate of $1.4 \times 10^{9} \mathrm{~kg}$ year ${ }^{-1}$ for this period. After $6,000 \mathrm{BP}$, the rate of eustatic sea level rise had strongly decreased. A remaining relative sea level rise during the last 5,000 years was caused by land subsidence, mainly due to compaction of previously deposited deltaic sediments (Cohen
2003; Gouw and Erkens 2007; Erkens 2009). Nevertheless, the lower relative sea level rise allowed the delta to gradually expand in upstream direction. Under these conditions, considerable peat formation occurred, indicating that sediment supply was not sufficient to fill the available accommodation space (Erkens 2009). It is, therefore, likely that the trapping efficiency of the delta was relatively high, particularly when compared to fluvial valley environments (Erkens 2009). This suggests that the bulk of the overbank sediment delivered to the delta was trapped on its way to the North Sea.

\subsection{Late Holocene (3000-1000 BP) deposition rates}

After 3000 BP, a distinct shift in sedimentation occurred: peat formation in the flood basins almost ceased while overbank sedimentation increased across the entire delta (Berendsen and Stouthamer 2000; Cohen 2005; Erkens 2009). Furthermore, two northern branches became active, and sedimentation began along the Utrechtse Vecht (after 3000 BP), (Bos et al. 2009) and the Gelderse IJssel (after 1500 BP) (Makaske et al. 2008; Erkens 2009). This expansion of the delta was no longer solely determined by relative base level rise but was also the result of increasing sediment deposition. A total mass of $4.2 \times 10^{12} \mathrm{~kg}$ sediment was deposited between 3000 and $1000 \mathrm{BP}$, comprising $3.2 \mathrm{~km}^{3}$. The average deposition amount over this time slice is $2.1 \times 10^{9} \mathrm{~kg}$ year $^{-1}$. Since the creation of accommodation space did not significantly change compared to the middle Holocene, the enhanced deposition must be attrib-

Table 1 Amount of overbank fine sediment deposition during different phases in the past

\begin{tabular}{|c|c|c|c|c|c|}
\hline Time slice & Compartment & $\begin{array}{l}\text { Volume } \\
{\left[10^{9} \mathrm{~m}^{3}\right]}\end{array}$ & $\begin{array}{l}\text { Mass } \\
{\left[10^{9} \mathrm{~kg}\right]}\end{array}$ & $\begin{array}{l}\text { Amount per year } \\
{\left[10^{9} \mathrm{~kg} \mathrm{year}^{-1}\right]}\end{array}$ & $\begin{array}{l}\text { Amount per year }+ \text { remob }^{\mathrm{a}} \\
{\left[10^{9} \mathrm{~kg} \mathrm{year}^{-1}\right]}\end{array}$ \\
\hline Mid-Holocene (6000-3000 BP) & Rhine delta & 3.18 & 4,134 & 1.38 & - \\
\hline Late Holocene (3000-1000 BP) & Rhine delta & 3.22 & 4,186 & 2.09 & - \\
\hline \multirow[t]{7}{*}{ After embankment (1300-1850 AD) } & Rhine branches & 0.39 & 508 & 0.92 & 1.62 \\
\hline & IJssel & 0.14 & 187 & 0.34 & 0.55 \\
\hline & Nederrijn-Lek & 0.12 & 160 & 0.29 & 0.52 \\
\hline & Waal & 0.12 & 161 & 0.29 & 0.55 \\
\hline & Biesbosch & 0.17 & 221 & 0.40 & 0.40 \\
\hline & Extracted floodplain clay & 0.10 & 131 & 0.24 & 0.24 \\
\hline & Total & 0.66 & 860 & 1.56 & 2.26 \\
\hline \multirow[t]{7}{*}{ After normalisation (1850-present) } & Rhine branches & 0.11 & 138 & 0.92 & 0.92 \\
\hline & IJssel & 0.03 & 40 & 0.27 & 0.27 \\
\hline & Nederrijn-Lek & 0.03 & 34 & 0.23 & 0.23 \\
\hline & Waal & 0.05 & 62 & 0.41 & 0.41 \\
\hline & Biesbosch & 0.00 & 0 & 0.00 & 0.00 \\
\hline & Extracted floodplain clay & 0.03 & 35 & 0.23 & 0.23 \\
\hline & Total & 0.13 & 173 & 1.15 & 1.15 \\
\hline
\end{tabular}

${ }^{a}$ When including sediment remobilized during the time slice 


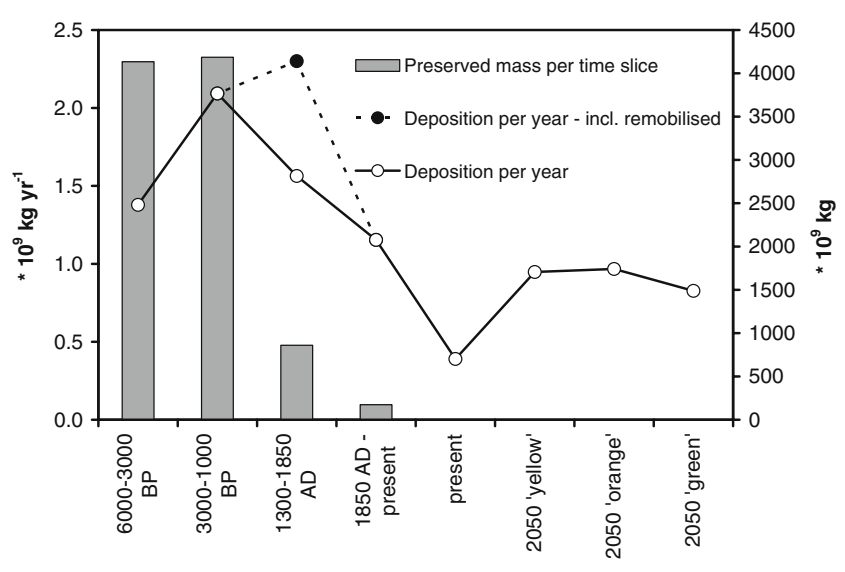

Fig. 3 Deposition amounts per time slice (bars) and per year (line). The present and 2050 yearly deposition amounts do not include the amounts deposited in the estuary

uted to increased sediment delivery from the Rhine drainage basin. This late-Holocene increase in sediment load matches the documented increase in erosion and sediment delivery in upstream valleys, resulting from progressive forest clearance for agriculture which started by the Bronze Age and expanded during the Iron, Roman and Middle Ages (Kalis et al. 2003; Mäckel et al. 2003; Hoffmann et al. 2007, 2009; Ward 2009; Erkens 2009). Although the climate has varied as well in this period, with climate optima during Roman and Middle Ages, the changes in climate were too subtle to explain the major increases in hillslope erosion reported from upstream valleys and sediment deposition in the Rhine delta. In particular, the high sediment deposition since the Roman Age must be attributed to human land use change (Erkens 2009).

\subsection{Post-embankment deposition rates: 1300-1850 AD}

\subsubsection{Floodplains}

The average thickness of overbank fines in the embanked floodplain area is about $1.8 \mathrm{~m}$ for the Waal floodplain and about $1.7 \mathrm{~m}$ for the other Rhine branches. The present-day total volume is $0.50 \mathrm{~km}^{3}$, which is equivalent to an amount of $0.64 \times 10^{12} \mathrm{~kg}$. Based on the depth over which increased metal concentrations occur in floodplain profiles from several sites, about $79 \%$ of these floodplain clays, i.e., $0.39 \mathrm{~km}^{3}$ is estimated to be pre- 1850 .

\subsubsection{Biesbosch inland delta}

A major additional amount of fluvial overbank fines was deposited in the Biesbosch delta. The post-1421 deltaic splay deposit is characterised by bars of medium and fine sand dissected by channels. Most of the sand, up to $4 \mathrm{~m}$ thick, was deposited proximally along the central axis of the delta (NE$\mathrm{SW})$. The deltaic sand is capped by $1-3 \mathrm{~m}$ of freshwater intertidal floodplain deposits that accumulated mostly after 1600. In the east, progressive reclamations took place in the eighteenth and nineteenth century. Downstream from the Biesbosch area, sediment has continued to accumulate until today. Deposition of overbank silts and clays in the Biesbosch amounted to $0.17 \mathrm{~km}^{3}$, which mainly occurred between 1600 and $1850 \mathrm{AD}$.

\subsubsection{Clay extraction}

Van der Meulen et al. (2009) estimated the annual and cumulative volumes of clay extraction using recent clayproduction figures since 1980 in combination with production statistics of bricks and roof tiles for 1938-1991 and extrapolated the results back in time assuming a relationship between brick production and economic growth (gross domestic product). The resulting total amount of clay extraction from the Rhine floodplains between 1850 and present equals $0.13 \mathrm{~km}^{3}$, which is an average rate of $0.9 \times$ $10^{6} \mathrm{~m}^{3}$ year $^{-1}$. Most of the clay extracted after $1850 \mathrm{AD}$ was deposited before 1850 . We estimated that about $0.1 \mathrm{~km}^{3}$ of this volume was pre-1850 clay and $0.03 \mathrm{~km}^{3}$ post- 1850 clay.

\subsubsection{Total deposition}

When adding the total amount of pre-1850 embanked floodplain clays, the floodplain clays in the Biesbosch splay, and the amount of excavated clay, the resulting total amount of floodplain deposition between 1300 and 1850 is $0.86 \times 10^{12} \mathrm{~kg}$, which is equivalent to a volume of $0.66 \mathrm{~km}^{3}$. This corresponds to a net accumulation rate of $1.56 \times$ $10^{9} \mathrm{~kg} \mathrm{year}^{-1}$. However, the actual deposition rate will have been considerably larger. Old river maps and the current floodplain morphology indicate that about $90 \%$ of the embanked Waal, about $80 \%$ of the embanked NederrijnLek and $60 \%$ of the embanked IJssel floodplain were reworked between 1300 and 1850. Using these reconstructed erosion values, the derived accumulation rates were converted to the actual deposition rates for the 1300-1850 period. This results in a total reconstructed deposition of $1.6 \times 10^{12} \mathrm{~kg}$ and an actual deposition rate of $2.26 \times$ $10^{9} \mathrm{~kg}$ year $^{-1}$. The latter amount is larger than the estimated deposition rate before embankment. Assuming that the trapping efficiency of the embanked floodplains was smaller than the natural delta means that the sediment delivery to the delta during the $1300-1850$ period was larger than in the Late Holocene and, presumably, also than to date. This fits well with many reconstructions that show medieval land use to be more intense compared to earlier and later periods (e.g., Lang et al. 2003) and with extremely 
high suspended load values measured during the late nineteenth century (Ward 2008).

\subsection{Post-normalisation deposition rates: 1850 -present}

The net post-1850 accumulation comprises the currently present amounts of overbank clays plus the amounts that have been extracted since 1850 for brick production. Using heavy metal profiles in floodplain sediments, Middelkoop (2002) estimated average deposition rates of overbank fines on different transects across the lower Rhine floodplains for the past century to vary between 0.2 and $10 \mathrm{~mm}$ year ${ }^{-1}$. Sedimentation rates on the Waal floodplain have been higher than on the Nederrijn-Lek and IJssel floodplains. The sedimentation rates decrease with increasing distance from the river channel but may be higher in local depressions. A minor dike may reduce the sedimentation rate by a factor of 2 to 3. Hobo et al. (2010) found local deposition rates varying between 3 and $10 \mathrm{~mm}$ year $^{-1}$ for the past decades, using optically stimulated luminescence dating (Wallinga 2001) and heavy metal profile characteristics (Wallinga et al. 2010). These values represent total annual amounts of clay deposition in the order of $0.4-3.7 \times$ $10^{9} \mathrm{~kg}$ year $^{-1}$ over the entire embanked floodplain area. Based on the depth of metal contamination, the total volume of floodplain sediments deposited since 1850 is about $0.11 \mathrm{~km}^{3}$, equivalent to a mass of $0.14 \times 10^{12} \mathrm{~kg}$. Accounting for clay extraction the estimated total deposition is $0.17 \times$ $10^{12} \mathrm{~kg}$. On average, this is about $1.15 \times 10^{9} \mathrm{~kg} \mathrm{year}^{-1}$.

The trapped amounts of sediment in the floodplains after channel normalisation were thus considerably lower than in the preceding period. This is likely mainly due to the fact that the main channel no longer could erode and migrate laterally, which prevented the "resetting" of the overbank deposition process. Instead, floodplain sedimentation continued uninterrupted by erosion, which resulted in increasingly higher floodplain surfaces with low flooding frequencies and inherent lower deposition rates (Middelkoop 1997). The construction of minor embankments further prevented flooding and sediment deposition on the embanked floodplains. In addition, sediment yield from the Rhine basin might have decreased after $1850 \mathrm{AD}$. In the course of the twentieth century, large areas in the Rhine basin became reforested, which must have reduced soil erosion and sediment yield. In the same period, large-scale river works were undertaken in the Rhine basin (Buck et al. 1993). Channel banks were protected from erosion, preventing them to function as a sediment source, while many stretches of the upstream Rhine tributaries were regulated by weirs that trap sediment.

\subsection{Current deposition rates}

At present, about $3.1 \times 10^{9} \mathrm{~kg}$ - with year-to-year variations between about $2.8 \times 10^{9}$ and $3.4 \times 10^{9} \mathrm{~kg}$ - suspended sediment reaches the Rhine delta at the German-Dutch border each year (Table 2). This sediment is distributed over the lower Rhine branches along with the discharge distribution; the Waal River carries about $2 \times 10^{9} \mathrm{~kg}_{\text {year }}{ }^{-1}$. Sediment trap measurements undertaken by Middelkoop and Asselman (1998), Asselman and Middelkoop (1998) and Thonon (2006) show that present-day deposition amounts on the embanked floodplains during individual flood events are in the order of $0.5-7.5 \mathrm{~mm}$ year $^{-1}$. These values are in line with Asselman and Van Wijngaarden (2002) who calculated deposition of suspended sediments on the floodplains using a combination of a 1D hydraulic model and a settling model for the floodplains and found an average value of $1.3 \mathrm{~mm}_{\text {year }}{ }^{-1}$. This corresponds to a total annual deposition equal to $0.48 \times 10^{9} \mathrm{~kg} \mathrm{year}^{-1}$.

Results obtained using the SEDIFLUX model show typical contemporary overbank sedimentation rates for different locations and reaches of the Rhine floodplains varying between 0.1 and $9 \mathrm{~mm}$ year $^{-1}$. The average annual accumulation rate for the entire embanked floodplains is or $0.39 \times 10^{9} \mathrm{~kg}$ year $^{-1}$ of which $0.09 \times 10^{9} \mathrm{~kg} \mathrm{year}^{-1}$ is deposited on the IJssel floodplain, $0.12 \times 10^{9} \mathrm{~kg} \mathrm{year}^{-1}$ on the Nederrijn-Lek floodplain and $0.19 \times 10^{9} \mathrm{~kg} \mathrm{year}^{-1}$ on

Table 2 Present-day suspended sediment budget of the lower Rhine

\begin{tabular}{lllll}
\hline & Compartment & Amount per year $\left[10^{9} \mathrm{~kg} \mathrm{year}^{-1}\right]$ & From total & $\begin{array}{l}\text { Sediment trapping efficiency } \\
\text { Per branch }\end{array}$ \\
\hline Inflow & Rhine at Lobith & 3.10 & - & - \\
Deposition & Rhine branches & 0.39 & 0.13 & - \\
& IJssel & 0.09 & 0.03 & 0.26 \\
& Nederrijn-Lek & 0.12 & 0.04 & 0.17 \\
& Waal & 0.19 & 0.06 & - \\
& Clay extraction & 0.68 & 0.81 & - \\
Outflow & Rhine Estuary & 2.50 & 0.06 & - \\
\hline
\end{tabular}


the Waal floodplain (see Table 2). The corresponding sediment trap efficiencies for the lower Rhine branches (calculated as the trapped amount divided by the total amount entering each branch) are 0.26 for the IJssel, 0.17 for the Nederrijn-Lek and 0.09 for the Waal. This larger trapping for the IJssel is due to its smaller main channel compared to the floodplain area, whilst the large main channel and relatively narrow floodplain area along the Waal result in a low trapping efficiency of this branch. The total annual conveyance loss due to overbank sedimentation is $13 \%$ of the total annual suspended sediment load entering the delta at Lobith. Current amounts of clay extraction are about $0.68 \times$ $10^{9} \mathrm{~kg} \mathrm{year}^{-1}$, which is remarkably larger that the annual floodplain deposition.

The largest trapping of suspended sediment occurs in the Rhine estuary, in the deep Rotterdam harbour area and Haringvliet, where each year $2.5 \times 10^{9} \mathrm{~kg}$ of fine fluvial sediments settle, which is $81 \%$ of the incoming fluvial suspended sediment (Ten Brinke 2005). About $0.2 \times$ $10^{9} \mathrm{~kg} \mathrm{year}^{-1}$, which is $6 \%$ of the incoming amount at Lobith, discharges into the North Sea.

\subsection{Future deposition rates}

Estimates of future sediment trapping are applied to the Waal River. Being the largest Rhine distributary, we assume that it represents the entire lower Rhine floodplain area. The KNMIW climate scenario results in higher winter discharge of the lower Rhine (Shabalova et al. 2003), which will lead to more frequent inundation of the floodplains. Consequently, the annual sediment deposition will increase by $58 \%$. However, landscaping measures will more than double the floodplain sedimentation rate, which will increase by $112 \%$ (Green scenario), 143\% (Yellow scenario) and 148\% (Orange scenario) when compared to the present-day situation. Spatial differentiation between the scenarios is considerable; large increases in deposition will occur where minor embankments are removed, floodplain surface is lowered and side channels are dug.

\section{Conclusions}

The Rhine delta has experienced several phases with remarkably different deposition amounts and rates during the past millennia. These changes can be attributed to different controls that were dominant during subsequent phases in the Holocene sedimentary history of the delta. Between 6000 and 3000 cal year BP, deposition of fine overbank sediment took mainly place in large backswamp areas behind the coastal barrier. Here, accommodation space was created by relative sea level rise (i.e. land subsidence), and the combination of peat lands and subsidence made the delta an efficient sediment trap. After $3000 \mathrm{BP}$, human intervention in the upstream basin became increasingly important. The expansion of agriculture at the cost of the forest cover resulted in an increase in sediment yield to the Rhine River. During the centuries before embankment, this resulted in a large accumulation of overbank fines in the entire delta. Since more than $80 \%$ of these deposits have been preserved, residence time of fine deposits in the natural, pre-embanked, delta is relatively long.

The establishment of artificial levees resulted in a dramatic decrease of total deposition amounts on the embanked floodplains when considered over the entire period 1300-1850. This is due to the poor preservation of the deposits. Until 1850, the main channels could laterally migrate and so eroded previously deposited overbank fines. Consequently, the residence time of the overbank fines in this period was on average much shorter than for the preembankment overbank deposits. The resulting remobilisation of previously deposited sediment will have formed a secondary local sediment source. However, assuming that lateral erosion and remobilisation occurred during (near) bankful discharge, most of these sediments may have been carried to the estuary. When accounting for the remobilisation, annual deposition rates were considerably higher. Due to the wide and shallow river channel, and the periodic rejuvenation of the floodplains, new low floodplain areas inundated frequently and could trap large amounts of overbank fines during a flood.

The normalisation works after 1850 resulted in a deeper main channel, while floodplains were no longer eroded. Inundation frequency of the aggrading floodplains decreased over time, resulting in decreasing sedimentation rates. As a result, the present-day trapping of sediment by the embanked floodplains is relatively low: $13 \%$ of the sediment load entering the delta at Lobith, and the majority of the suspended sediment passes the floodplain reaches and is deposited in the estuary. The preservation of this post-normalisation floodplain sediment has been large: clay excavation for brick factories and the digging of sand pits were the only anthropogenic processes that caused removal of clay from the embanked floodplains after 1850 .

In the coming century, climate change causes increased flooding of the embanked floodplains, accelerating overbank deposition by nearly $60 \%$. This means an increase of the small trapping efficiency of the present-day floodplains from $13 \%$ to $20 \%$. In contrast, the landscaping measures as foreseen in the scenarios to prevent increasing flood water levels result in a substantial increase in the interaction of water and sediment between the main channel and the floodplain. This will considerably increase the floodplains' natural function as traps of overbank fines, as it will 
increase the trapping efficiency to $30 \%$ of the incoming suspension load at Lobith.

This sequence of deposition episodes and underlying causes of the changes in deposition excellently demonstrate how different external forcings - both in the upstream basin and in the delta itself-have determined and changed the role of the Rhine floodplain as a trap of overbank fines during the past millennia. Especially the impact of humans on sedimentation in the Rhine delta shows an interesting pattern. During the prehistory, humans had an indirect impact when deforestation upstream increased the delivery of fines to the Rhine delta. From medieval times, the direct role of humans became apparent when they embanked the deltaic channels and changed the functioning of the delta (resulting in lower trap efficiency of the delta). From the nineteenth century onwards, parts of the Rhine catchment were reforested and indirect human impact diminished. However, in the same period, direct human impact strongly increased with the normalisation of the Rhine, both in the delta and upstream. The construction of groynes and dams impacted sediment delivery to the delta (lower) and the functioning of the delta (lower trap efficiency, higher preservation).

In the present-day Rhine delta, the trap efficiency, preservation of deposits and upstream sediment delivery are all strongly determined by human action and can be regarded as highly unnatural. The many proposed landscaping measures will considerably rehabilitate the natural role of the floodplains as traps for fluvial sediment conveyed from the continents to the coastal zone.

Acknowledgements The authors are grateful to the reviewers Thomas Hoffmann and Paul Rustomji for their constructive comments on the earlier version of the manuscript.

Open Access This article is distributed under the terms of the Creative Commons Attribution Noncommercial License which permits any noncommercial use, distribution, and reproduction in any medium, provided the original author(s) and source are credited.

\section{References}

Asselman NEM, Middelkoop H (1998) Temporal variability of contemporary floodplain sedimentation in the Rhine-Meuse delta, The Netherlands. Earth Surf Process Landf 23:595609

Asselman NEM, Van Wijngaarden M (2002) Development and application of a 1D floodplain sedimentation model for the River Rhine in the Netherlands. J Hydrol 268:127-142

Beets DJ, Van der Spek AJF (2000) The Holocene evolution of the barrier and the back-barrier basins of Belgium and the Netherlands as a function of late Weichselian morphology, relative sea-level rise and sediment supply. Neth J Geosci 79:3-16

Berendsen HJA (2005) De Laaglandgenese Databank. CD-ROM, Department of Physical Geography, Faculty of Geosciences, Utrecht University, Utrecht
Berendsen HJA, Stouthamer E (2000) Late-Weichselian and Holocene palaeogeography of the Rhine-Meuse delta, The Netherlands. Palaeogeogr Palaeoclimatol Palaeoecol 161:311-335

Berendsen HJA, Stouthamer E (2001) Palaeogeographic development of the Rhine-Meuse delta, The Netherlands. Van Gorcum, Assen

Bianchi TS, Allison MA (2009) Large-River Delta-Front Estuaries as Natural "Recorders" of Global Environmental Change. Proc Natl Acad Sci 106(20):8085-8092

Bos IJ, Feiken H, Bunnik F, Schokker J (2009) Influence of organics and clastic lake fills on distributary channel processes in the distal Rhine-Meuse delta (The Netherlands). Palaeogeogr Palaeoclimatol Palaeoecol 284:355-374

Buck W, Felkel K, Gerhard H, Kalweit H, Van Malde J, Nippes KR, Ploeger B, Schmitz W (1993) Der Rhein unter der Einwirkung des Menschen - Ausbau, Schifffahrt, Wasserwirtschaft / Le Rhin sous l'influende de l'homme - Aménagement, navigation, gestion des eaux. KHR Report I-11. KHR, Lelystad

Cohen KM (2003) Differential subsidence within a coastal prism: LateGlacial - Holocene tectonics in the Rhine-Meuse delta, The Netherlands. Dissertation, Utrecht University. Neth Geogr Stud 316

Cohen KM (2005) 3D geostatistical interpolation and geological interpolation of palaeo-groundwater rise within the coastal prism in the Netherlands. In: Giosan L, Bhattacharaya JP (eds) River Deltas: Concepts, Models, and Examples, vol. 83. SEPM Special Publication, pp. 341-364

Erkens G (2009) Sediment dynamics in the Rhine catchment: Quantification of fluvial response to climate change and human impact. Dissertation, Utrecht University. Neth Geogr Stud 388

Erkens G, Cohen KM, Gouw MJP, Middelkoop H, Hoek WZ (2006) Holocene sediment budgets of the Rhine Delta (The Netherlands): a record of changing sediment delivery. In: Rowan JS, Duck RW, Werritty A (eds) Sediment Dynamics and the Hydromorphology of Fluvial Systems, vol 306. IAHS, Idyllwild, pp 406415

Gouw MJP (2008) Alluvial architecture of the Holocene RhineMeuse delta (the Netherlands). Sedimentology 55:1487-1516

Gouw MJP, Erkens G (2007) Architecture of the Holocene RhineMeuse delta (the Netherlands) A result of changing external controls. Neth J Geosci 86:23-54

Hesselink AW (2002) History makes a river-morphological changes and human interference in the river Rhine, The Netherlands. Dissertation, Utrecht University, Neth Geogr Studies 292

Hesselink AW, Weerts HJT, Berendsen HJA (2003) Alluvial architecture of the human-influenced river Rhine, The Netherlands. Sediment Geol 161:229-248

Hijma MP, Cohen KM, Hoffmann G, Van der Spek AJF, Stouthamer E (2009) From river valley to estuary: the evolution of the Rhine mouth in the early to mid Holocene (western Netherlands, Rhine-Meuse delta). Neth J Geosci 88:13-53

Hobo N, Makaske B, Middelkoop H, Wallinga J (2010) Reconstruction of floodplain sedimentation rates: a combination of methods to optimise estimates. Earth Surf Process Landf (in press)

Hoffmann T, Erkens G, Cohen KM, Houben P, Seidel J, Dikau R (2007) Holocene floodplain sediment storage and hillslope erosion within the Rhine catchment. Holocene 17(1):105-118

Hoffmann T, Erkens G, Gerlach R, Klostermann J, Lang A (2009) Trends and controls of Holocene floodplain sedimentation in the Rhine catchment. Catena 77:96-106

Kalis AJ, Merkt J, Wunderlich J (2003) Environmental changes during the Holocene climatic optimum in central Europe - human impact and natural causes. Quat Sci Rev 22:33-79

Kleinhans MG, Weerts HJT, Cohen KM (2010) Avulsion in action: reconstruction and modelling sedimentation pace and upstream flood water levels following a Medieval tidal-river diversion catastrophe (Biesbosch, The Netherlands, 1421-1750 AD). Geomorph. doi:10.1016/j.geomorph.2009.12.009 
Lang A, Bork HR, Mäckel R, Preston N, Wunderlich J, Dikau R (2003) Changes in sediment flux and storage within a fluvial system: some examples from the Rhine catchment. Hydrol Process 17:3321-3334

Mäckel R, Schneider R, Seidel J (2003) Anthropogenic impact on the Landscape of Southern Badenia (Germany) during the Holocene documented by colluvial and alluvial sediments. Archaeometry 45 (3):487-501

Makaske B, Maas GJ, Van Smeerdijk DG (2008) The age and origin of the Gelderse IJssel. Neth J Geosci 87:323-337

Middelkoop H (1997) Embanked floodplains in the Netherlands. Dissertation, Utrecht University, Neth Geogr Studies 224

Middelkoop H (2000) Heavy-metal pollution of the river Rhine and Meuse floodplains in the Netherlands. Neth J Geosci 79:411-428

Middelkoop H (2002) Reconstructing floodplain sedimentation rates from heavy metal profiles by inverse modelling. Hydrol Process $16: 47-64$

Middelkoop H, Asselman NEM (1998) Spatial variability of floodplain sedimentation at the event scale in the Rhine-Meuse delta, The Netherlands. Earth Surf Process Landf 23:561-573

Middelkoop H, Van der Perk M (1998) Modelling spatial patterns of overbank sedimentation on embanked floodplains. Geogr Ann 80A(2):95-109

Middelkoop H, Van Haselen COG (1999) Twice a river. Rhine and Meuse in the Netherlands. RIZA Report No. 99.033. RIZA, Arnhem

Ministry V\&W (2009) WAQUA/TRIWAQ - two- and threedimensional shallow water flow model. Technical documentation. SIMONA report number 99-01, Version 3.6, February 2009. Ministry of Transport, Public Works and Water Management, The Hague, www.waqua.nl

Shabalova MV, Van Deursen WPA, Buishand TA (2003) Assessing future discharge of the river Rhine using regional climate model integrations and a hydrological model. Clim Res 23:233-246

Straatsma MW, Schipper A, Van der Perk M, Van den Brink NGM, Middelkoop H, Leuven RSEW (2009) Impact of value-driven scenarios on the geomorphology and ecology of lower Rhine floodplains under a changing climate. Landsc Urban Plan 92:160 174

Syvitsky JPM (2003) Supply and flux of sediment along hydrological pathways: research for the 21st century. Glob Planet Change 39:1-11

Ten Brinke WBM (2005) The Dutch Rhine, a restrained River. Veen Magazines, Diemen

Thonon I (2006) Deposition of sediment and associated heavy metals on floodplains Dissertation, Utrecht University, Neth Geogr Studies 337
Thonon I, De Jong K, Van der Perk M, Middelkoop H (2007) Modelling floodplain sedimentation using particle tracking. Hydrol Process 21:1402-1412

Törnqvist TE (1993) Fluvial sedimentary geology and chronology of the Holocene Rhine-Meuse delta, The Netherlands. Dissertation, Utrecht University, Neth Geogr Studies 166

Van den Hurk BJJM, Klein Tank AMG, Lenderink G, van Ulden AP, van Oldenborgh GJ, Katsman CA et al (2006) KNMI climate change scenarios 2006 for the Netherlands. KNMI, De Bilt

Van der Meulen MJ, Van Gessel SF, Veldkamp JG (2005) Aggregate resources in the Netherlands. Neth J Geosci 84:379-387

Van der Meulen MJ, Van der Spek AJF, De Lange G, Gruijters SHLL, Van Gessel SF, Nguyen BL, Maljers D, Schokker J, Mulder JPM, Van der Krogt RAA (2007) Regional sediment deficits in the Dutch Lowlands: implications for long-term land-use options. J Soils Sediments 7:9-16

Van der Meulen MJ, Wiersma AP, Van der Perk M, Middelkoop H, Hobo N (2009) Sediment management and the renewability of floodplain clay for structural ceramics. J Soils Sediments 9:627-639

Van der Perk M, Straatsma MW, Middelkoop H, Van den Brink NGM (2008) Quantification of fine sediment retention in the Rhine delta using a two-dimensional floodplain sedimentation model. Geophys Res. Abstr 10:EGU2008-A-05566

Wallinga J (2001) The Rhine-Meuse system in a new light: optically stimulated luminescence dating and its application to fluvial deposits. Dissertation, Utrecht University, Neth Geogr Studies 290

Wallinga J, Hobo N, Cunningham AC, Versendaal AJ, Makaske A, Middelkoop H (2010) Sedimentation rates on embanked floodplains determined through quartz optical dating. Quat Geochronol 5:170 175

Ward PJ (2008) River Meuse suspended sediment yield: a new estimate and past estimates revisited. Neth J Geosci 87:189-193

Ward PJ (2009) Simulating discharge and sediment yield characteristics in the Meuse basin during the late Holocene and 21st Century. Dissertation, VU University Amsterdam

Weerts HJT, Bierkens MFP (1993) Geostatistical analysis of overbank deposits of anastomosing and meandering fluvial systems; Rhine-Meuse delta, the Netherlands. Sediment Geol 85:221-232

Wolfert HP (2001) Geomorphological change and river rehabilitation: Case Studies on Lowland Fluvial Systems in the Netherlands. $\mathrm{PhD}$ Thesis, Scientific Publications 6, Alterra Green World Research, Wageningen

Zonneveld IS (1960) De Brabantse Biesbosch, a study of soil and vegetation of a freshwater tidal delta. VO1. A,B,C. PUDOC, Wageningen 